\title{
Maternal health care access among migrant women labourers in the selected brick kilns of district Faridabad, Haryana: mixed method study on equity and access
}

\author{
Archana Siddaiah ${ }^{1 *}$, Shashi Kant ${ }^{2}$, Partha Haldar², Sanjay K. Rai ${ }^{2}$ and Puneet Misra²
}

\begin{abstract}
Background: Socio-economic inequity leads to health inequity. Inequity is closely intertwined with internal migration. This study was planned with the objective of documenting the maternal health care utilization among women labourers working in brick kilns situated in an area of Haryana, north India.

Methods: A community based mixed method study was done in select brick kilns of Faridabad district in north India. A mixed method study was done to assess maternal health care utilization in a sample of 500 women in the reproductive age group. Focus group discussions were also carried out. Descriptive analysis was done. Qualitative data was analysed using the thematic framework approach.

Results: The mean age of the women was 30 (SD 0.3) years. Mean number of pregnancies per woman was 3.1 (SD 1.7). Only $22.9 \%$ ever had institutional delivery. About one third of women had ever received cash benefit under Janani SurakshaYojana (JSY) or had ever used free ambulance services. Seven major themes emerged from the qualitative analysis. Important themes include-Gaps in knowledge regarding local health system; Sub-standard private health care delivered at brick kilns prevent migrants from accessing the basic public health services; Misconceptions and mistrust about public health system influenced maternal health care utilization; Barriers to avail universal health coverage: location of brick kilns, time, apathy of public health system, partial health insurance cover.

Conclusions: A typical migrant woman labourer in the brick kiln was an illiterate, had migrated from poor states, belonged to a socially disadvantaged community and worked long hours, and had been doing so for many years. This study has identified migrant women working in brick kilns as a vulnerable population subgroup in terms of maternal health utilization. To achieve universal health care it is important to understand the needs of all population subgroups and make concerted efforts at the health system level.
\end{abstract}

Keywords: Maternal healthcare, Migrant, Brick kiln, Mixed method study, Equity, Access, India

\section{Introduction}

One of the most pressing global issues is the growing rates of socio-economic inequity [1]. India is the second most populous country in the world with a fast-growing economy which has become more unequal in recent years [2]. Inequity is closely intertwined with internal migration [3].

\footnotetext{
* Correspondence: archanapink@yahoo.com; archana.s@stjohns.in 'Department of Community Health, St John's National Academy of Health Sciences, No 321 Annex 1, Sarjapur road, John Nagar, Kormangala, Bengaluru 560034 , India

Full list of author information is available at the end of the article
}

The National Sample Survey Organization (NSSO) has defined migrants as those for whom the last usual place of residence, where the person had stayed continuously for a period of 6 months or more, is different from the present place of enumeration [4]. According to estimates three out of every ten Indians are migrants [3]. Such migrants mainly work in the informal sector, are responsible for $90 \%$ of the workforce and about $50 \%$ of the national product [5]. In India, informal sector consists of industries related to construction, agriculture, textiles, brick making, stone quarries and many others [5]. The brick kiln

(C) The Author(s). 2018 Open Access This article is distributed under the terms of the Creative Commons Attribution 4.0 International License (http://creativecommons.org/licenses/by/4.0/), which permits unrestricted use, distribution, and 
industry is a labour intensive industry involved in producing bricks which are an indispensable component of construction activity. The brick kiln industry in India is next to China in terms of global production having more than 100,000 kilns, employing about 10 million workers [6]. Labourers usually belong to underprivileged sections of society especially rural areas and indulge in circular migration i.e., seasonal migration typically seeking work. This is emerging as a dominant form of migration amongst poorer groups in India [7, 8]. These migrants go with family to work in brick kilns along with their children. This seasonal migration varies from 4 to 6 months in duration usually during September to June which is an agriculturally inactive period in their native villages.

Due to India's fast urbanization, building construction is estimated to grow at a rate of $6.6 \%$ per year between 2005 and 2030 [9]. Naturally, there would be a proportional growth of brick industry and migrants working in this industry. Consequently, the health of the workers in this industry assumes importance. Maternal and child health is largely influenced by social determinants. Circular migration affects health service utilization and thus the health status of women and children who are most vulnerable. Efforts by the government in increasing access to maternal health has been unequal and many such migrant women still lack access to basic maternal health care [10]. Countries like Sri Lanka, Malaysia and Hong Kong which are nearing achieving universal health care are the ones in which their poorest people made no use of private health care [1]. Increasingly, many global studies have found disparities in terms of health among migrants and natives in terms of access to basic health care [11-15].

Even though many studies on migrants are directed towards non-communicable diseases, few studies have reported maternal and child health status of migrants. Surveys such as National Family Health Survey (NFHS), and the District Level Household Survey (DLHS) did not consider migration as a variable affecting the health status in general, and maternal health in particular $[16$, 17]. Therefore, we wanted to assess the effect of socially produced inequities on maternal health care utilization among migrants which remains unknown. Hence, we planned this study with the objective of documenting the maternal health care utilization among women labourers working in the brick kilns situated in an area of Haryana, north India. Studying this would help us identifying actionable areas which can be aimed to reduce health inequities in such vulnerable settings.

\section{Methodology}

\section{Study design}

This study was an exploratory, community-based, mixed method study [18], having both quantitative (cross sectional) and qualitative components.

\section{Study setting}

Faridabad is a district of Haryana in north India, constituting a part of National Capital Region. According to 2011 census, Faridabad recorded a growth rate of 31.7\% compared to $20 \%$ for whole of Haryana [19]. Ballabgarh was one of the administrative blocks in Faridabad where two Primary Health Centres (PHCs) namely, Dayalpur and Chhainsa are situated [20]. Study was conducted in the brick kilns that were located within these two PHC areas. There was a total of 70 brick kilns in this area. The total number of labourers varied between brick kilns, approximately 20 to 100 families per brick kiln.

\section{Study population and study period}

For this study migrant women in the reproductive age (15-45 years) working in the brick kilns that were situated in and around the above mentioned PHCs were included. Adult men and women labourers in these brick kilns were included for focus group discussions (FDGs). The study was conducted from April 2015 and Dec 2015.

\section{Sample size}

Since the exact count of migrant women in the reproductive age (15-45 years) working in the brick kilns was not available, an estimation of number of women labourers at brick kilns was done by interviewing all brick kiln supervisors telephonically. The estimated number of such women labourers was 1838 . Since this was an exploratory study it was decided to study 500 women. Two stage random sampling was done. Inclusion criteria were women within the reproductive age group, history of at least one child birth, currently working in brick kiln, and able to understand and speak in Hindi.

\section{Quantitative study tools}

An interview schedule was prepared in English and translated to local language (Hindi). The interview schedule broadly captured the participant's demographic and socio-economic information, report of antenatal care, receipt of iron and folic acid (IFA) supplements, and maternal health care access for the most recent pregnancy. Interview schedule was finalised after pretesting by one of the co-investigators in one brick kiln which was excluded from the present study. Four research assistants were trained over 3 days to collect data. They conducted face to face interviews with all participants in their homes at their respective brick kilns. Co-investigator supervised the data collection in the field.

\section{Qualitative}

Focus groups were considered ideal for exploring the dynamics of migration and health service utilization and 
also to understand migrants' perspective on this. An FGD guide was prepared with eight open ended questions with suitable probes. Separate FGDs (6-8 participants per FGD) were conducted for men and women. A total of five FGDs were conducted by AS (doctor, trained in qualitative research) in Hindi in the brick kilns. With the consent of each participant, FGDs were audio taped. Field notes were made, when required. Each FGD lasted for 35-50 min. After each interview, the key points were summarized by the interviewer and verified as a way of participant validation.

\section{Statistical analysis}

Data was entered into Epi Info 7 software, and analysed in Stata12 (Stata Statistical Software TX: StataCorp LP). Logistic regression was done to determine the predictive factors for maternal health care utilization. Lorenz curve and Gini index was also calculated for measuring inequity. Thematic framework approach was used for qualitative data analysis [21, 22]. A descriptive content analysis by manual coding was done by two independent, trained researchers $(\mathrm{AS}, \mathrm{PH})$ to generate basic themes (Table 1). Results

Table 1 Thematic framework used for understanding the maternal health care utilization of migrant women working in selected brick kilns in Faridabad, India

\begin{tabular}{ll}
\hline 1 & Reasons for migration to the place of work \\
\hline 1.2 & Repayment of loan \\
1.3 & Inability to earn livelihood at the place of origin \\
1.4 & Delayed disbursement of NREGA payments \\
2.1 & Work pattern in brick kilns \\
2.2 & Labor intense work \\
2.3 & Long working hours \\
3 & Facilities available at brick kilns \\
4 & Public health system at the place of work \\
5.1 & Available health care \\
5.2 & Non-utilization of public health facilities \\
5.3 & Private health system at the place of work \\
6.1 & Maternal health care availed by laborers \\
6.2 & Janani Suraksha Yojana \\
6.3 & Knowledge about emergency transport facility \\
7 & Utilization of social service schemes \\
8 & National health insurance coverage (RSBY) \\
$9.1 \quad$ Inability to avail maternal health care \\
9.2 Lack of time, and awareness \\
9.3 Failure of public health system in planning migrant health services \\
$9.4 \quad$ Private providers more appealing to laborers \\
$10 \quad$ Possible ways to deliver health care to migrant laborers in brick kilns \\
\hline NREGA- National Rural Employment Guarantee Scheme; RSBY-Rashtriya Swasthya \\
Bhima Yojana
\end{tabular}

were organized under several broad themes. Verbatim quotes were reported for each theme. Results were reported as per the consolidated criteria for reporting qualitative studies (COREQ) guidelines [21].

\section{Ethical issues}

Ethical clearance was obtained from the Ethics Committee of All India Institute of Medical Sciences, New Delhi before conducting the study (Ref no- RT-8/25.02.2015). Informed written consent was taken from participants and the left thumb print was taken for those who were unable to write. Upon completion of the study, a poster was distributed to all brick kilns which contained details about the nearest government health facilities and details of maternal health services available there.

\section{Results}

\section{Quantitative}

A total of 518 women were interviewed in the quantitative survey. The mean age of the women was 30 (SD 0.3) years and mean age at marriage was 17.3 (SD 2.3) years. Majority of women (67.3\%) were illiterate and $36.1 \%$ of their spouse was illiterate (Table 2). Almost $60 \%$ of

Table 2 Socio-demographic details of the migrant women labourers working in selected brick kilns in Faridabad, India $(n=518)$

\begin{tabular}{|c|c|c|c|}
\hline SI no & Variables & Number & Percentage \\
\hline \multirow[t]{5}{*}{1} & State of origin & & \\
\hline & Chhattisgarh & 363 & 70.1 \\
\hline & Uttar Pradesh & 56 & 10.8 \\
\hline & Rajasthan & 24 & 4.6 \\
\hline & Others & 75 & 14.5 \\
\hline 2 & $\begin{array}{l}\text { Education status of women } \\
\text { (illiterate) }\end{array}$ & 349 & 67.3 \\
\hline 3 & $\begin{array}{l}\text { Education status of husband } \\
\text { (illiterate) }\end{array}$ & 187 & 36.1 \\
\hline 3 & $\begin{array}{l}\text { Involved in agricultural work } \\
\text { in native place }\end{array}$ & 476 & 91.9 \\
\hline \multirow[t]{3}{*}{4} & Caste & & \\
\hline & $\mathrm{SC} / \mathrm{ST}$ & 423 & 81.7 \\
\hline & Others & 95 & 18.3 \\
\hline \multirow[t]{4}{*}{5} & $\begin{array}{l}\text { Most important reason for working } \\
\text { in brick kilns }\end{array}$ & & \\
\hline & Repayment of debt & 230 & 44.4 \\
\hline & More money in brick kilns & 145 & 28.0 \\
\hline & No work in native place & 131 & 25.3 \\
\hline 6 & $\begin{array}{l}\text { Mean years of working in brick } \\
\text { kilns (SD) }\end{array}$ & $7.4(3.7)$ & - \\
\hline 7 & $\begin{array}{l}\text { Women's mean hours of working } \\
\text { in brick kilns (SD) }\end{array}$ & $10.7(2.5)$ & - \\
\hline 8 & Median income per season & 30,000 & - \\
\hline
\end{tabular}

SC/ST-Scheduled caste and Scheduled tribe; SD-Standard deviation 
women reported possessing Below Poverty Line (BPL) card, and $47.9 \%$ had Rashtriya Swasthya BhimaYojana (RSBY- national health insurance) card [23].

Mean age at first pregnancy was 18.8 (SD 2.2) years. Only $22.9 \%$ ever delivered a baby in a hospital. Availability of good hospital facility encouraged majority of participants $(60.1 \%)$ to have institutional delivery. The most common reason for home delivery was ease of having home delivery and absence of any problem during pregnancy (64.7\%). About one third of women had ever received cash benefit under Janani Suraksha Yojana (JSY) [24] or had ever used free ambulance services (Tables 3 and 4). Majority of participants (67.4\%) preferred government facility for maternal health care as they were provided services free of cost (Table 5).

Variables were tested for association with outcome variables viz. ANC and place of delivery. (Table 4). Variables that were significantly associated were put into the regression model. Logistic regression analysis showed that younger age, involved in agricultural work in the place of origin, and visit by health worker or ASHA were some of the important predictors for maternal health care utilization. (Tables $6 \& 7$ ).

The Gini index was found to be 0.2184 . Since the inequality is more if this index is closer to 1 , the inequality in our sample was not very high. Figure 1 depicts the

Table 3 Details of last pregnancy and delivery of migrant women labourers working in selected brick kilns in Faridabad,

\begin{tabular}{|c|c|c|c|}
\hline SI no & Variable & Number & Percentage \\
\hline 1 & Details of last pregnancy & & \\
\hline 1.1 & $\begin{array}{l}\text { Received some antenatal care during } \\
\text { the last pregnancy }\end{array}$ & 389 & 75.1 \\
\hline 1.2 & Received iron and folic acid tablet & 200 & 38.6 \\
\hline 1.3 & Haemoglobin test done & 336 & 64.9 \\
\hline 1.4 & Received tetanus toxoid injection & 416 & 80.3 \\
\hline 2 & Place of delivery & & \\
\hline 2.1 & Home delivery & 399 & 77.1 \\
\hline 2.2 & Hospital delivery & 119 & 22.9 \\
\hline 3 & Contraceptive usage & & \\
\hline 3.1 & Ever used any contraceptive & 145 & 28.0 \\
\hline 3.2 & Underwent tubectomy $(n=145)$ & 106 & 73.1 \\
\hline 4 & $\begin{array}{l}\text { Facilities available for pregnant } \\
\text { women }\end{array}$ & & \\
\hline 4.1 & Ever heard about JSY services & 233 & 45.0 \\
\hline 4.2 & Ever received JSY money & 159 & 30.7 \\
\hline 4.3 & $\begin{array}{l}\text { Ever heard about free ambulance } \\
\text { facility }\end{array}$ & 381 & 73.6 \\
\hline 4.4 & Ever used free ambulance facility & 189 & 36.5 \\
\hline
\end{tabular}

JSY Janani Suraksha Yojana
Lorenz curve using the population proportion against the cumulative percentage of income.

\section{Qualitative}

Five FGDs were conducted, three involving all women labourers and two involving men labourers. All of them aged between 18 and 46 years of age. Seven major themes emerged from the analysis, i.e., 1) Inability to earn livelihood at place of origin; 2) Laborious work in brick kilns often involving pregnant women; 3) Gaps in knowledge regarding local health system; 4) Sub-standard private health care delivered at brick kilns prevent migrants from accessing the basic public health services; 5) Misconceptions and mistrust about public health system influenced maternal health care utilization; 6) Barriers to avail universal health coverage: location of brick kilns, time, apathy of public health system, partial health insurance cover;7) As part of universal health coverage concerted efforts by the public health system to address maternal health needs of migrant women (Table 8).

Gaps in knowledge regarding local health system: Many participants were not aware of the existing local health systems which impaired their healthcare utilization. Many also mentioned that they knew about free ambulance facility at their place of origin but not at the place of work.

\section{Male participant 4: "We have no information about ambulance".}

By visiting brick kilns private providers induce migrant labourers to utilize private health service: Poor access to public health systems facilitated private providers to target such migrant labourers for monetary gains.

\section{Male participant 2: "We usually take medicines from one RMP doctor [private provider] who come in bicycle [to brick kiln]...". \\ Female participant 8: "RMP charges rupees 150 for medicines and rupees 500 for injections".}

Pregnant women working in brick kilns sent home for child birth: For child birth public health facility was preferred. Due to various reasons women labourers were unable to avail maternal health services at the place of work.

Female participant 10: "Sometimes we send pregnant women back home [place of origin] for delivery...in case of emergency we call our supervisor to take patient to government hospital". 
Table 4 Determinants of ANC and place of delivery among migrant women working in selected brick kilns in Faridabad, India $(n=518)$

\begin{tabular}{|c|c|c|c|c|c|c|}
\hline \multirow[t]{2}{*}{ Variable } & \multicolumn{2}{|l|}{ Antenatal care ${ }^{a}$} & \multirow[t]{2}{*}{$p$ value } & \multicolumn{2}{|l|}{ Place of delivery } & \multirow[t]{2}{*}{$p$ value } \\
\hline & Adequate $(n=278)$ & Inadequate $(n=240)$ & & Institutional $(n=175)$ & Home $(n=343)$ & \\
\hline Mean age (SD) & $28.2(6.3)$ & $32(6.9)$ & 0.000 & $26.1(5.1)$ & $31.9(6.8)$ & 0.000 \\
\hline \multicolumn{7}{|l|}{ Stay in brick kiln } \\
\hline Long & $95(18.3)$ & $130(25.1)$ & 0.000 & $58(11.2)$ & $167(31.7)$ & \\
\hline Short & $183(35.3)$ & $110(21.2)$ & & $117(22.6)$ & 179 (34.6) & 0.000 \\
\hline \multicolumn{7}{|c|}{ Participant Education } \\
\hline Illiterate & $169(32.6)$ & $180(34.8)$ & & $92(17.8)$ & $257(49.6)$ & \\
\hline Literate & $109(21.0)$ & $60(11.6)$ & 0.001 & $83(16.0)$ & 86 (16.6) & 0.000 \\
\hline \multicolumn{7}{|l|}{ Occupation } \\
\hline Agriculture & $238(45.0)$ & $165(31.8)$ & & $126(24.3)$ & $102(19.7)$ & \\
\hline Others & $40(7.7)$ & $75(14.5)$ & 0.000 & $49(9.5)$ & $241(46.5)$ & 0.000 \\
\hline \multicolumn{7}{|l|}{ Income } \\
\hline$\leq 25,000$ & $97(18.7)$ & $112(21.6)$ & & 89 (17.2) & $120(23.2)$ & \\
\hline$>25,000$ & $181(34.9)$ & $128(46.3)$ & 0.006 & 86 (16.6) & $223(43.1)$ & 0.000 \\
\hline \multicolumn{7}{|l|}{$H$ visit } \\
\hline Yes & $225(43.4)$ & $105(20.3)$ & & $107(20.7)$ & $223(43.1)$ & \\
\hline No & $53(10.2)$ & $135(46.3)$ & 0.000 & $68(13.1)$ & $120(23.2)$ & 0.386 \\
\hline \multicolumn{7}{|l|}{ ASHA visit } \\
\hline Yes & $247(47.7)$ & $160(30.9)$ & & $139(26.8)$ & $268(51.7)$ & \\
\hline No & $31(6.0)$ & $80(15.4)$ & 0.000 & $36(7.0)$ & $75(14.5)$ & 0.734 \\
\hline \multicolumn{7}{|l|}{ Used ambulance } \\
\hline Yes & - & - & & 87 (16.8) & $102(19.7)$ & \\
\hline No & - & - & - & $88(17.0)$ & 241 (46.5) & 0.000 \\
\hline
\end{tabular}

${ }^{a}$ Adequate Antenatal care was defined as received some antenatal care, $\pi$ injections, and IFA tablets

Table 5 Reasons for health system preference for general ailments and maternal health care among migrant women labourers working in select brick kilns in Faridabad, India $(n=518)$

\begin{tabular}{|c|c|c|c|c|c|}
\hline $\begin{array}{l}\text { Preference for general ailments } \\
(n=509)^{\mathrm{a}}\end{array}$ & $\begin{array}{l}\text { Reason for } \\
\text { preference }\end{array}$ & $\begin{array}{l}\text { Number } \\
\text { (Percent) }\end{array}$ & $\begin{array}{l}\text { Preference for maternal } \\
\text { care }(n=505)^{b}\end{array}$ & $\begin{array}{l}\text { Reason for } \\
\text { preference }\end{array}$ & $\begin{array}{l}\text { Number } \\
\text { (Percent) }\end{array}$ \\
\hline \multirow[t]{6}{*}{ Government 204 (39.8) } & Accessible & $23(11.3)$ & Government 340 (67.4) & Accessible & $17(5.0)$ \\
\hline & Free treatment & $139(68.1)$ & & Ambulance & $54(15.9)$ \\
\hline & Quality care & $34(16.7)$ & & Free treatment & $159(46.8)$ \\
\hline & Others & $8(3.9)$ & & Quality care & $45(13.2)$ \\
\hline & - & & & JSY & $43(12.6)$ \\
\hline & - & & & Others & $22(6.5)$ \\
\hline Sub-total & & $204(100)$ & & & $340(100)$ \\
\hline \multirow[t]{5}{*}{ Private 305 (59.5) } & Government not good & $41(13.4)$ & Private 164 (32.6) & Accessible & $26(15.9)$ \\
\hline & Accessible & $84(27.5)$ & & Doctor came home & $8(4.9)$ \\
\hline & Doctor came home & $37(12.1)$ & & Quality care & $57(34.8)$ \\
\hline & Quality care & $126(41.3)$ & & Others & $73(44.5)$ \\
\hline & Others & $17(5.6)$ & & - & \\
\hline Sub-total & & $305(100)$ & & & $164(100)$ \\
\hline
\end{tabular}


Table 6 Predictors of ANC using logistic regression among migrant women working in selected brick kilns in Faridabad, India $(n=518)$

\begin{tabular}{|c|c|c|c|c|}
\hline \multirow{2}{*}{$\begin{array}{l}\text { SI } \\
\text { no }\end{array}$} & \multirow[t]{2}{*}{ Predictor variable } & \multicolumn{2}{|l|}{ Antenatal care ${ }^{a}$} & \multirow{2}{*}{$\begin{array}{l}\text { Odds ratio } \\
\text { with } 95 \% \\
\text { confidence } \\
\text { interval }\end{array}$} \\
\hline & & Adequate $(n=278)$ & Inadequate $(n=240)$ & \\
\hline \multirow[t]{4}{*}{1} & Participant age & & & \\
\hline & $17-25(n=178)$ & 71.35 & 28.65 & 1 \\
\hline & $26-35(n=236)$ & 48.73 & 51.27 & $0.7(0.6-1.0)$ \\
\hline & $36-45(n=104)$ & 34.62 & 65.38 & $2.25(1.63-3.12)$ \\
\hline \multirow[t]{3}{*}{2} & Participant education & & & \\
\hline & Literate $(n=109)$ & 64.50 & 35.50 & 1 \\
\hline & Illiterate $(n=169)$ & 48.42 & 51.58 & $1.07(.67-1.68)$ \\
\hline \multirow[t]{3}{*}{3} & Stay in brick kilns & & & \\
\hline & Short $(n=293)$ & 62.46 & 37.54 & 1 \\
\hline & Long $(n=225)$ & 42.22 & 57.78 & $1.27(.82-1.97)$ \\
\hline \multirow[t]{3}{*}{4} & Income & & & \\
\hline & $>25,000(n=309)$ & 58.58 & 41.42 & 1 \\
\hline & $\leq 25,000(n=209)$ & 46.41 & 53.59 & $.61(.40-.92)$ \\
\hline \multirow[t]{3}{*}{5} & Work in native place & & & \\
\hline & Agriculture (403) & 59.06 & 40.94 & 1 \\
\hline & Non agriculture $(n=115)$ & 34.78 & 65.22 & $2.17(1.33-3.53)$ \\
\hline \multirow[t]{3}{*}{6} & Health worker visit & & & \\
\hline & Yes $(n=330)$ & 68.18 & 31.82 & 1 \\
\hline & No $(n=188)$ & 28.19 & 71.81 & $4.06(2.57-6.42)$ \\
\hline \multirow[t]{3}{*}{7} & ASHA worker visit & & & \\
\hline & Yes $(n=407)$ & 60.69 & 39.31 & 1 \\
\hline & No $(n=111)$ & 27.93 & 72.07 & $1.96(1.12-3.41)$ \\
\hline
\end{tabular}

${ }^{a}$ Adequate Antenatal care was defined as received some antenatal care, $\pi$ injections, and IFA tablets

Failure of public health system to provide health services for migrants: Apathy of public health system to act to the needs of migrants emerged as one of the important themes.

Female participant 12: "We don't know what kinds of services are available here for pregnant women. Even if someone becomes ill we don't know what to do".

Summary of results of qualitative analysis is summarised as barriers and possible solutions for improving maternal health care utilization for migrant women labourers (Table 9).

\section{Discussion}

This study was done to assess the maternal health care utilization among migrant women. The mean age of women was 30 (SD 0.3) years and the mean age at first pregnancy was 17.3 (SD 2.3) years. Previous studies have reported lower age at first pregnancy among migrants compared to natives [25]. Many women labourers in brick kilns matched this socio-demographic profile.

\section{Inadequate antenatal care}

WHO recommends that pregnant women should receive focussed antenatal care as it is an important determinant of safe delivery [26]. Our study found inadequate antenatal care. In this study although 3/4th of all women had at least one contact with formal health sector yet only $38.6 \%$ had received iron folic acid tablet. In rural Haryana $18.6 \%$ pregnant women consumed 100 iron and folic acid (IFA) tablets during pregnancy [16]. Given the low receipt and still lower compliance of IFA tablets, the problem of anaemia remains largely unaddressed among most of the participants. Poor access to basic health care due to socioeconomic disparities is associated with worse healthcare utilization and health outcomes [2729]. Women in brick kilns were living in a medically underserved region and faced barriers to health care access such as inaccessible transportation. There was no special effort from public health system to reach out to 
Table 7 Predictors of place of delivery using logistic regression among migrant women working in selected brick kilns in Faridabad, India $(n=518)$

\begin{tabular}{|c|c|c|c|c|}
\hline \multirow{2}{*}{$\begin{array}{l}\text { SI } \\
\text { no }\end{array}$} & \multirow[t]{2}{*}{ Predictor variable } & \multicolumn{2}{|l|}{ Place of delivery } & \multirow{2}{*}{$\begin{array}{l}\text { Odds ration } \\
\text { with } 95 \% \\
\text { confidence } \\
\text { interval }\end{array}$} \\
\hline & & Institutional $(n=175)$ & Home $(n=343)$ & \\
\hline \multirow[t]{4}{*}{1} & Participant age & & & \\
\hline & $17-25(n=178)$ & 57.30 & 42.70 & 1 \\
\hline & $26-35(n=236)$ & 27.54 & 72.46 & $.9(.6-1.2)$ \\
\hline & $36-45(n=104)$ & 7.69 & 92.31 & $2.88(2.03-4.08)$ \\
\hline \multirow[t]{3}{*}{2} & Participant education & & & $1.64(1.03-2.59)$ \\
\hline & Literate $(n=109)$ & 49.11 & 50.89 & 1 \\
\hline & Illiterate $(n=169)$ & 26.36 & 73.64 & $1.60(1.0-2.5)$ \\
\hline \multirow[t]{3}{*}{3} & ANC utilization ${ }^{a}$ & & & \\
\hline & Adequate $(n=278)$ & 41.01 & 58.99 & 1 \\
\hline & Inadequate $(n=240)$ & 25.42 & 74.58 & $1.5(.9-2.4)$ \\
\hline \multirow[t]{3}{*}{4} & Income & & & \\
\hline & $>25,000(n=309)$ & 27.83 & 72.17 & 1 \\
\hline & $\leq 25,000(n=209)$ & 42.58 & 57.42 & $2.3(1.5-3.7)$ \\
\hline \multirow[t]{3}{*}{5} & Work in native place & & & \\
\hline & Agriculture (403) & 31.27 & 68.73 & 1 \\
\hline & Non agriculture $(n=115)$ & 42.61 & 57.39 & $.34(.2-.5)$ \\
\hline \multirow[t]{3}{*}{6} & Used ambulance & & & \\
\hline & Yes $(n=189)$ & 46.03 & 53.97 & 1 \\
\hline & No $(n=329)$ & 26.75 & 73.25 & $2.3(1.4-3.8)$ \\
\hline
\end{tabular}

${ }^{a}$ Adequate Antenatal care was defined as received some antenatal care, $\pi$ injections, and IFA tablets

migrants. In such a situation migrants relied on unregulated private providers for basic health care.

\section{Place of delivery}

This study was conducted 10 years after Government of India (GOI) launched National Health Mission (NHM), still only $22.9 \%$ had institutional delivery while the institutional delivery rate for rural Haryana that was $80 \%$.The frequently mentioned reasons for home delivery in this study was "no problem during pregnancy", and "home delivery was easy". Many women were not aware of the local health facilities. So, it is reasonable to

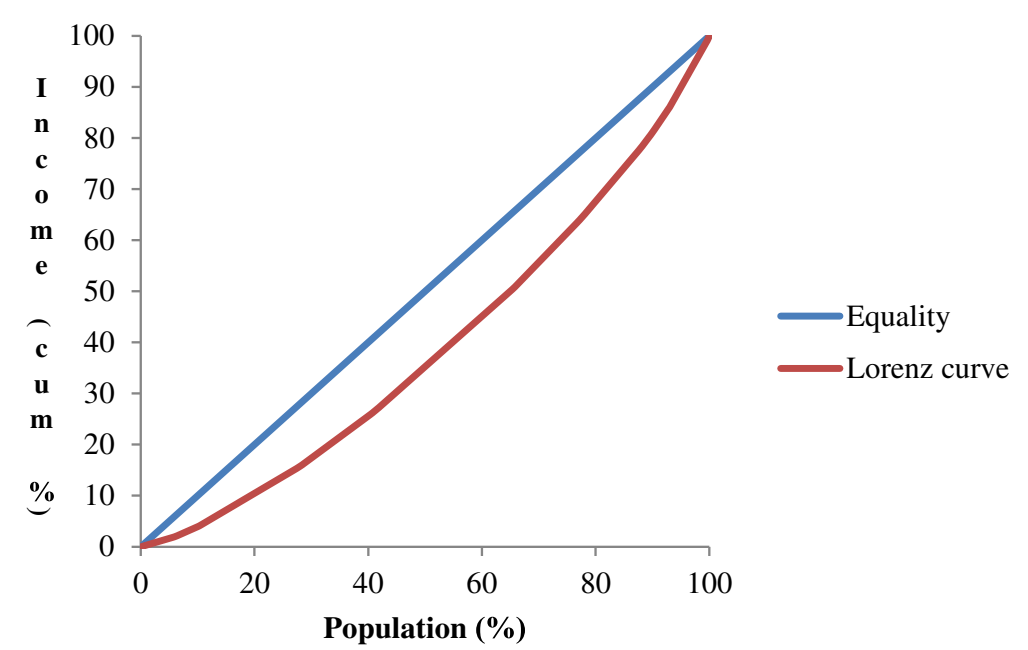

Fig. 1 Lorenz curve for household income inequality among the migrant women labourers working in select brick kilns in Faridabad, India $(n=518)$ 


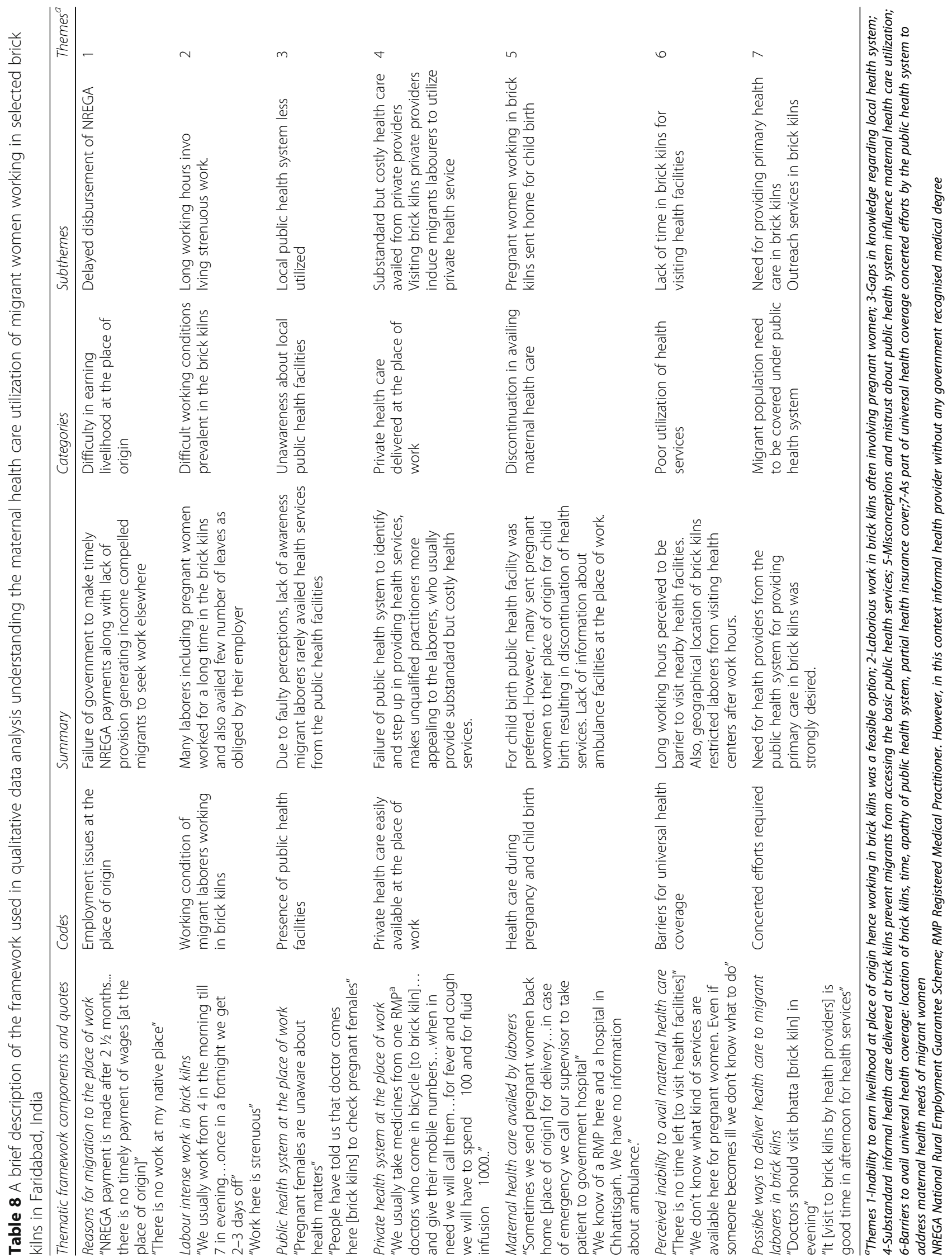


Table 9 Barriers and solutions identified for maternal health care utilization by migrant women working in selected brick kilns in Faridabad, India

\begin{tabular}{|c|c|}
\hline Barriers & Solutions \\
\hline $\begin{array}{l}\text { Lack of income generating activities in the place of origin resulting in } \\
\text { migration }\end{array}$ & $\begin{array}{l}\text { Rural employment Government must step up efforts such as NREGA to } \\
\text { improve the livelihood of people; early payment of NREGA wages; }\end{array}$ \\
\hline Low awareness & IEC about the maternal health issues \\
\hline Prolonged working hours in the brick kilns & $\begin{array}{l}\text { Prescribing minimum work time for the labourers working in } \\
\text { unorganised sector }\end{array}$ \\
\hline Unfamiliarity of local setting in the place of work & Assistance from the brick kiln employers; IEC \\
\hline $\begin{array}{l}\text { Private providers capitalizing on the prevailing situation of migrant } \\
\text { labourers preventing them from seeking basic public health care }\end{array}$ & $\begin{array}{l}\text { Sensitizing private providers about the need for migrant labourers to } \\
\text { have access for universal health coverage; Regulation of unqualified } \\
\text { private providers; }\end{array}$ \\
\hline $\begin{array}{l}\text { Absence of an existing channel thorough which public health care can } \\
\text { be delivered to migrant labourers; Disruption in continuing maternal } \\
\text { health care at the place of work }\end{array}$ & $\begin{array}{l}\text { Deployment of health providers such as ASHA; Migrant mobile health } \\
\text { unit to help migrant labourers continue accessing public health system } \\
\text { even at the place of work }\end{array}$ \\
\hline Underutilization of emergency transport facility, JSY & $\begin{array}{l}\text { Awareness campaign regarding birth preparedness and complication } \\
\text { readiness }\end{array}$ \\
\hline Issues in availing benefits from the national insurance scheme & Strengthening of RSBY to achieve universal health coverage \\
\hline Public health system's apathy in providing migrant specific health care & $\begin{array}{l}\text { Strategies targeting migrant labourers to be incorporated in the National } \\
\text { health programmes such as NHM }\end{array}$ \\
\hline
\end{tabular}

NREGA- National Rural Employment Guarantee Scheme; IEC-Information Education and Communication; ASHA-Accredited Social Health Activist; JSY-Janani Suraksha Yojana; RSBY-Rashtriya Swasthya Bhima Yojana; NHM-National Health Mission

assume that birth preparedness was lacking. Majority $(81.7 \%)$ of women in our study belonged to SC/ST, a disadvantaged section which is associated with poor uptake of antenatal care. Age wise break up of institutional delivery showed that older women had less institutional delivery rate. Women's social class, and more number of years in brick kilns along with location of brick kilns might have limited the access to institutional care at the time of delivery. Circular migration has also shown to affect health service uptake at place of origin [7]. Many preferred government health facility for care during pregnancy and opted for institutional delivery if good facility, free treatment, and quality of care was available. Unfortunately, this was not the case at the place of work which explains the low proportion of institutional delivery.

\section{Referral transport, JSY, and health insurance}

Even though two thirds of women were aware about free referral transport, only $36.5 \%$ had ever utilised it. A time series analysis done in 2013observed that institutional deliveries in Haryana rose significantly after the introduction of free referral transport [30]. Rural women utilized ambulance for reaching a health facility during labour irrespective of presence or absence of complication. However, participants in this study revealed that they did not utilise ambulance during labour as they felt they did not have any problem. Many also mentioned that they knew about free ambulance facility at their place of origin but not at their work place. Some participants mentioned that they would go back to their place of origin before delivery making continuity of care difficult. However, it is known that women would be more comfortable at their place of origin. There may be many reasons for this such as social support, familiarity with the health facility. Interestingly, only $45 \%$ of participants had heard about JSY scheme, which was launched as a flagship programme under NHM in 2005 to increase institutional delivery. GOI introduced the RSBY in 2012, a national insurance scheme for workers of unorganised sector [23]. In our study partial health insurance cover: barrier to avail universal health coverage was an important theme. This was also affirmed during quantitative analysis as less than half possessed an RSBY card. Poverty, illiteracy, residing away from native place, location of brick kilns, and frequent movement contributed to less utilization of such schemes among migrants which in turn leads to unequal access to health care.

\section{Possible solutions}

Firstly, mapping of such unorganised migrant settlements and reaching out to them through the public health system is needed. Intense information education and communication activities targeted to migrant populations about the existing public health facilities, free referral transport, RSBY is an important strategy. Since JSY is a $100 \%$ centrally funded scheme, the health system could become flexible to provide cash incentives for institutional delivery to migrants at their place of work. It must be ensured that migrants avail maternal and child health care with zero out-of-pocket expenditure irrespective of work place. This is expected to increase the uptake of maternal health services. Under the mobile health map programme, migrant populations are 
accessing primary health care in the United States [31, 32]. Similarly, considering the seasonality of migration, local public health system must be sensitised to provide outreach maternal health services using dedicated migrant mobile health units involving frontline workforce such as ASHA (Accredited Social Health Activist). There is a scope to report how social inequity influence health indicators in national level surveys. For this NFHS and DLHS must include such migrant population in their surveys. Concerted efforts by the concerned stake holders within and outside public health system to address maternal health needs of migrant women is need of the hour to achieve universal health coverage.

\section{Strengths and limitations}

The strength of our study was its mixed methods design with the quantitative and qualitative components complementing each other. Limitations include lack of information on each pregnancy and its complications, and outcomes. Under reporting of heath care access could be possible since it was self reported. Cross sectional nature of the study did not allow us to capture the information over a longer time frame which would have given more insight for comparing maternal health care access at the place of origin and place of work. Since this was an exploratory study, results of the statistical tests needs to be interpreted cautiously. However, we feel that this study has provided some of the important predictors of low maternal health care utilization which needs to be confirmed by robust epidemiological studies. Also, only labourers from brick kilns (a part of unorganised sector) were included in this study.

\section{Conclusions}

Our study revealed that a typical migrant woman labourer in brick kiln was an illiterate; primarily worked as an agriculture labourer at her place of origin; had migrated from poor states; she belonged to the socially disadvantaged community and had chosen the present occupation out of indebtedness; she usually worked long hours and had been doing so for many years. This study has identified migrant women working in brick kilns as a vulnerable population subgroup in terms of maternal healthcare utilization. To achieve universal health coverage, it is important to consider the needs of all population subgroups. Research and advocacy focusing on the health of women migrants in unorganised sector should be encouraged. Unless government provides easily accessible, affordable and equitable health care to all its citizens especially poor migrants in line with natives, it is impossible to reduce the existing health inequity.

\section{Abbreviations}

ASHA: Accredited Social Health Activist; DLHS: District Level Household Survey; FGD: Focus Group Discussion; GOI: Government of India; IFA: Iron and Folic Acid; JSY: Janani Suraksha Yojana; NFHS: National Family Health Survey; NHM: National Health Mission; NREGA: National Rural Employment Guarantee Scheme; NSSO: National Sample Survey Organization; SC/ ST: Scheduled Caste and Scheduled Tribe; SD: Standard Deviation; WHO: World Health Organization

\section{Acknowledgements}

Authors are grateful to Dr. Arvind Kasturi for his inputs. Authors would like to acknowledge the participation and co-operation of all labourers and their employers.

\section{Funding}

None

\section{Availability of data and materials}

The datasets generated and/or analysed during the current study are not publicly available. However, an annonymised dataset is available from the corresponding author on reasonable request.

\section{Authors' contributions}

SA conceptualised the study design, gathered essential information for analysis, analysed the data, drafted and revised the manuscript. SK conceptualised the study design, contributed essential resources for conducting the study, revised the paper critically. PH contributed essential resources for conducting the study, revised the paper critically. SR contributed in study design, revised the paper critically. PM contributed in study design, revised the paper critically. All authors have read and approved the final version of this manuscript.

Ethics approval and consent to participate

Mentioned in the manuscript.

\section{Consent for publication}

None

Competing interests

The authors declare that they have no competing interests.

\section{Publisher's Note}

Springer Nature remains neutral with regard to jurisdictional claims in published maps and institutional affiliations.

\section{Author details}

${ }^{1}$ Department of Community Health, St John's National Academy of Health Sciences, No 321 Annex 1, Sarjapur road, John Nagar, Kormangala, Bengaluru 560034, India. ${ }^{2}$ Centre for Community Medicine, All India Institute of Medical Sciences, Ansari Nagar, New Delhi, India.

Received: 21 January 2018 Accepted: 1 November 2018 Published online: 20 November 2018

\section{References}

1. Even It Up. Time to end extreme inequality. Oxfam. 2013. https://www. oxfamamerica.org/static/media/files/even-it-up-inequality-oxfam.pdf. Accessed 15 July 2017.

2. Thorat S, Dubey A. Has growth been socially inclusive-1993-94-2009-10? Econ Polit Wkly. 2012;10:43-53.

3. Unesco, and Unicef I. For a Better Inclusion of Internal Migrants in India. 2012. http://unesdoc.unesco.org/images/0021/002191/219173e.pdf. Accessed 13 Nov 2017.

4. National Sample Survey Office. Ministry of statistics \& Programme implementation. Government of India Migration in India 2010. http://mospi.nic.in/sites/default/files/ publication_reports/533_final.pdf. Accessed 13 Nov 2017.

5. National Commission for Enterprises in the Unorganised Sector. Government of India. The challenge of employment in India. An informal economy perspective. 2009. http://dcmsme.gov.in/The_Challenge_of_ Employment_in_India.pdf. Accessed 13 Nov 2017.

6. Khan R, Vyas HA. Study of impact of brick industries on environment and human health in Ujjain city. India J Environ Res Dev. 2008;2(3):421-5.

7. Bird K, Deshingkar P. Circular migration in India. 2009. https://www.odi.org/ sites/odi.org.uk/files/odi-assets/publications-opinion-files/3381.pdf. Accessed 13 Nov 2017. 
8. Deshingkar P. Circular Internal Migration and Development in India. Overseas Development Institute, London.; p. 163-89.

9. Jain A. India's construction sector to boom - the Hindu. 2016. http://www. thehindu.com/features/homes-and-gardens/indias-construction-sector-toboom/article8314034.ece. Accessed 23 Aug 2017.

10. Sanneving L, Trygg N, Saxena D, Mavalankar D, Thomsen S. Inequity in India: the case of maternal and reproductive health. Glob Health Action. 2013:6:19145.

11. Sun $\mathrm{X}$, Chen M, Chan KL. A meta-analysis of the impacts of internal migration on child health outcomes in China. BMC Public Health. 2016;16(1):66.

12. Issaka Al, Agho KE, Renzaho AMN. The impact of internal migration on under-five mortality in 27 sub-Saharan African countries. Ciccozzi M, editor PLoS One 2016;11(10):e0163179.

13. Vu LTH, Nguyen NTK, Tran HTD, Muhajarine N. mHealth information for migrants: an e-health intervention for internal migrants in Vietnam. Reprod Health. 2016;13(1):55

14. Ebrahim S, Kinra S, Bowen L, Andersen E, Ben-Shlomo Y, Lyngdoh T, et al. The effect of rural-to-urban migration on obesity and diabetes in India: a cross-sectional study. PLoS Med. 2010;7(4):e1000268.

15. Todrys KW, Amon JJ. Within but without: human rights and access to HIV prevention and treatment for internal migrants. Glob Health. 2009;5(1):17.

16. District Level Household and Facility Survey 4. State Fact Sheet Haryana. 2012.

17. National family health survey, India [Internet]. Mumbai: International Institute for Population Sciences (IIPS) and Macro International; 2009. Available from: http://rchiips.org/nfhs/nfhs4.shtml. Accessed 23 Aug 2017.

18. Creswell JW, Plano Clark VL. Designing and conducting mixed methods research. California: SAGE Publications; 2010

19. District Census Handbook, Faridabad. Village and Town wise Primary Census Abstract. Census of India 2011. Haryana. 2011.

20. Kant S, Misra P, Gupta S, Goswami K, Krishnan A, Nongkynrih B, et al. The Ballabgarh health and demographic surveillance system (CRHSP-AllMS). Int J Epidemiol. 2013;42(3):758-68.

21. Tong A, Sainsbury P, Craig J. Consolidated criteria for reporting qualitative research (COREQ): a 32-item checklist for interviews and focus groups. Int J Qual Heal care J Int Soc Qual Heal Care. 2007;19(6):349-57.

22. Ritchie J, Lewis J, McNaughton Nicholls C, Ormston R. Qualitative research practice: a guide for social science students and researchers. SAGE Publications; New Delhi. 2014.

23. Karan A, Yip W, Mahal A. Extending health insurance to the poor in India: an impact evaluation of Rashtriya Swasthya Bima Yojana on out of pocket spending for healthcare. Soc Sci Med. 2017;181:83-92.

24. Ng M, Misra A, Diwan V, Agnani M, Levin-Rector A, De Costa A. An assessment of the impact of the JSY cash transfer program on maternal mortality reduction in Madhya Pradesh, India. Glob Health Action. 2014;7:24939.

25. Kusuma YS, Kumari R, Kaushal S. Migration and access to maternal healthcare: determinants of adequate antenatal care and institutional delivery among socio-economically disadvantaged migrants in Delhi, India. Tropical Med Int Health. 2013;18(10):1202-10.

26. Akshaya KM, Shivalli S, Kayombo E, Mbekenga C, Axemo P, Darj E. Birth preparedness and complication readiness among the women beneficiaries of selected rural primary health centers of Dakshina Kannada district, Karnataka, India. Puthussery S, editor PLoS One 2017;12(8):e0183739.

27. Devasenapathy N, Jerath SG, Allen E, Sharma S, Shankar AH, Zodpey S. Reproductive healthcare utilization in urban poor settlements of Delhi: baseline survey of ANCHUL (ante Natal and Child health care in urban slums) project. BMC Pregnancy Childbirth. 2015;15(1):212.

28. Yaya S, Bishwajit $\mathrm{G}$, Ekholuenetale M. Factors associated with the utilization of institutional delivery services in Bangladesh. Biswas A, editor PLoS One 2017;12(2):e0171573.

29. Hodge A, Firth S, Bermejo R, Zeck W, Jimenez-Soto E. Utilisation of health services and the poor: deconstructing wealth-based differences in facilitybased delivery in the Philippines. BMC Public Health. 2016;16(1):523.

30. Prinja S, Jeet G, Kaur M, Aggarwal AK, Manchanda N, Kumar R. Impact of referral transport system on institutional deliveries in Haryana, India. Indian J Med Res. 2014;139:883-91.

31. Report for the U.S. Department of Health and Human Services O of MH. Mobile health clinics in the United States. Mobile health map. 2013. https:/ www.mobilehealthmap.org/sites/default/files/Mobile_Health_Clinics_in_the_ United_States_March_2013.pdf. Accessed 24 Aug 2017.
32. Hill CF, Powers BW, Jain SH, Bennet J, Vavasis A, Oriol NE. Mobile health clinics in the era of reform. Am J Manag Care. 2014;20(3):261-4.

\section{Ready to submit your research? Choose BMC and benefit from:}

- fast, convenient online submission

- thorough peer review by experienced researchers in your field

- rapid publication on acceptance

- support for research data, including large and complex data types

- gold Open Access which fosters wider collaboration and increased citations

- maximum visibility for your research: over $100 \mathrm{M}$ website views per year

At BMC, research is always in progress.

Learn more biomedcentral.com/submissions 